\title{
Geometry change between 1990 and 2003 at Finsterwalderbreen, a Svalbard surge-type glacier, from GPS profiling
}

\author{
Richard HODGKINS, ${ }^{1}$ Adrian FOX, ${ }^{2}$ Anne-Marie NUTTALL ${ }^{3}$ \\ ${ }^{1}$ Department of Geography, Loughborough University, Loughborough, Leicestershire LE11 3TU, UK \\ E-mail: r.hodgkins@lboro.ac.uk \\ ${ }^{2}$ Mapping and Geographic Information Centre, British Antarctic Survey, Madingley Road, Cambridge CB3 OET, UK \\ ${ }^{3}$ School of Biological and Earth Sciences, Liverpool John Moores University, Byrom Street, Liverpool L3 3AF, UK
}

\begin{abstract}
Surface mass-balance and geometry data are key to quantifying the climate response of glaciers, and confidence in data synthesis and model interpretations and forecasts requires data from as wide a range of locations and glacier types as possible. This paper presents measurements of surface elevation change at the Svalbard surge-type glacier Finsterwalderbreen, by comparing a 1990 digital elevation model (DEM) with a surface GPS profile from 2003. The pattern of elevation change is consistent with that previously noted between 1970 and 1990, and reflects the continued quiescentphase evolution of the glacier, with mass loss in the down-glacier/receiving area of up to $-1.25 \mathrm{~m} \mathrm{w.e.} \mathrm{a}^{-1}$, and mass gain in the up-glacier/reservoir area of up to $0.60 \mathrm{~m} \mathrm{w.e.} \mathrm{a}^{-1}$; the area-weighted, mean change for the whole glacier is $0.19 \mathrm{~m}$ w.e. $\mathrm{a}^{-1}$. The spatial pattern of elevation increase and decrease is complex, and the boundary between thickening and thinning determined by combining GPS and DEM data does not appear to correspond with the equilibrium-line altitude determined from surface mass-balance measurements. There is no evidence yet of a decrease in the rate of reservoir area build-up driven by mass-balance change resulting from the warmer winter air temperatures, and decreased proportion of snowfall in total precipitation, noted at meteorological stations in Svalbard.
\end{abstract}

\section{INTRODUCTION}

Mass-balance data are needed to quantify the climate response of glaciers, their hydrological impact, and to drive and validate cryospheric models. However, only about 5\% of the total ice-covered area of Svalbard $\left(36600 \mathrm{~km}^{2}\right)$ has been subject to systematic mass-balance measurements (Hagen and others, 2003), and the majority of these measurements have been obtained at small $\left(\sim 5 \mathrm{~km}^{2}\right)$ glaciers in western and central Spitsbergen (Hagen and Liestøl, 1990). Such glaciers have shown no statistically significant trend in mass balance over about the past 30 years, and have probably had a consistently negative mass balance since about 1920 (Lefauconnier and Hagen, 1990). The area-altitude distribution is important, however: glaciers with significant area above $500 \mathrm{~m}$ a.s.l. are closer to zero balance than lower-lying glaciers (Hagen and others, 2003). Therefore, enhanced regional coverage from a wide variety of glacier types would be advantageous.

Furthermore, the proportion of glaciers in Svalbard which are surge-type has variously been estimated to be $90 \%$ (Lefauconnier and Hagen, 1991), 36\% (Hamilton and Dowdeswell, 1996) and 13\% (Jiskoot and others, 1998). It has been suggested that this proportion has decreased during the 20th century as more negative mass-balance conditions lead some glaciers to fail to accumulate sufficient mass to trigger renewed surges (Dowdeswell and others, 1995; cf. Eisen and others, 2001). Dowdeswell and others (1995) noted that the number of actively surging glaciers in the archipelago decreased from 18 to 5 over the period 193690, and attributed this to a general negative shift in mass balance following an abrupt air-temperature increase early in the 20th century. The role of mass balance in the regulation of surging has also been recognized at individual glaciers: Dyurgerov and others (1985) determined a critical mass balance for surge initiation at Medvezhiy glacier,
Tajikistan, from measured mass balances and local climatological data; Eisen and others (2001) found that the initiation of surges at Variegated Glacier, Alaska, USA, strongly correlated with the cumulative balance in the accumulation area since the last surge, and that the length of the quiescent phase was principally dependent upon the rate at which annual balances reached a critical level.

The purpose of this paper is to present and discuss measurements of surface elevation change at a Svalbard surge-type glacier, determined by comparison of surface global positioning system (GPS) profiling conducted in 2003 with a photogrammetrically derived digital elevation model (DEM) from 1990 (Fox and Nuttall, 1997). Hagen and others (1999) found that kinematic GPS profiling could successfully be applied to measure mass-balance change, given that it sampled the area-altitude distribution representatively. This contribution expands the body of glacier geometry change measurements from Svalbard in terms of location, glacier size and period of observation.

\section{LOCATION AND METHODS}

The work was based on Finsterwalderbreen, located at $77^{\circ} 31^{\prime} \mathrm{N}, 15^{\circ} 19^{\prime} \mathrm{E}$ in southern Spitsbergen, the largest island of the Norwegian Arctic archipelago of Svalbard (Figs 1 and 2). Finsterwalderbreen is a $12 \mathrm{~km}$ long, northwardflowing glacier fed by three small tributary glaciers, of which only one, Revtannbreen, is currently believed to be active (Nuttall and others, 1997). Excluding these tributaries, the glacier has a total area of $29.6 \mathrm{~km}^{2}$. The glacier has a polythermal temperature regime (Ødegård and others, 1997) and a history of regular surge activity (Hart and Watts, 1997; Nuttall and others, 1997), with the most recent surge occurring between 1898 and 1918. Since then the glacier terminus has thinned and retreated at a rate of $10-45 \mathrm{~m} \mathrm{a}^{-1}$ 


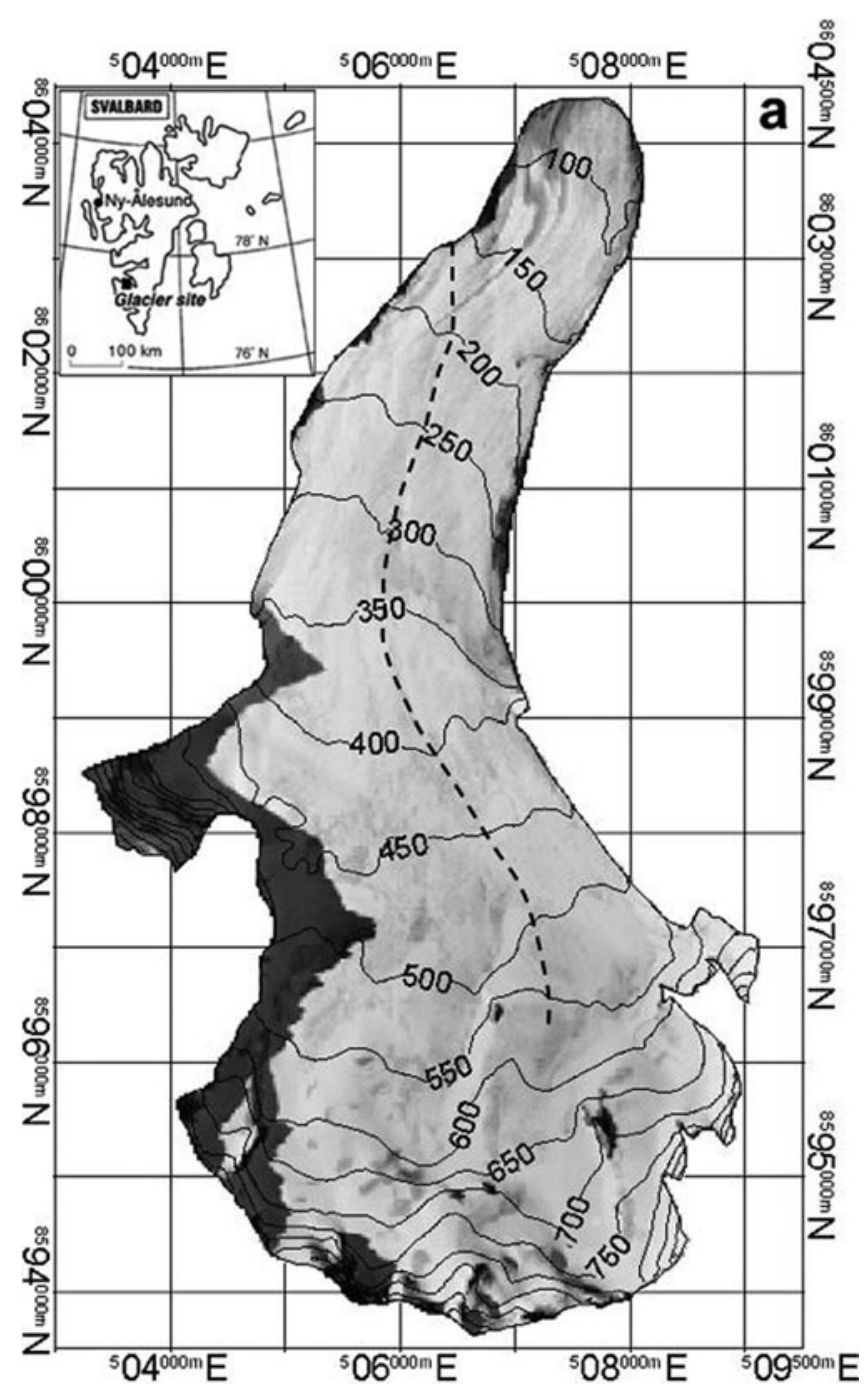

Fig. 1. Surface topography (m a.s.I.) of Finsterwalderbreen. Image is subset of aerial photographs S90 3741-3744 (C) Norwegian Polar Institute. Inset shows location within Svalbard. Scale and north direction are given by an underlying $1 \mathrm{~km}$ Universal Transverse Mercator (UTM) grid. The GPS profile is shown as the dashed line.

(Nuttall and Hodgkins, 2005). It is against this surge-type character that the geometry change of Finsterwalderbreen should be viewed. The dynamics, mass balance and hydrology of Finsterwalderbreen have been reported previously (e.g. Liestøl, 1969; Hagen and others, 2000; Wadham and others, 2001; Hodgkins and others, 2003).

Surface profiling was conducted on 12 August 2003 using Trimble 5700 geodetic-standard GPS (Fig. 1). A base station was established at a brass marker pin near the coast: coordinates for this base station are derived from GIPSYOASIS II high-precision post-processing of 18 hours of (RINEX-format) data collected at $1 \mathrm{~Hz}$; they agree to within $0.005 \mathrm{~m}$ elevation with coordinates collected similarly in 2005 using a Leica GPS. Profile data are derived from kinematic baseline processing to the base station, sampled at $1 \mathrm{~Hz}$. The accuracy of baseline processing is a few $\mathrm{mm}$. Predominantly, survey error relates to the method of conducting the profile: on foot, with the GPS antenna mounted on a pole of fixed length and secured into the side pocket of a rucksack. Errors are therefore generated by means such as leaning into the slope when walking uphill, slouching when tired, and the general motion of the

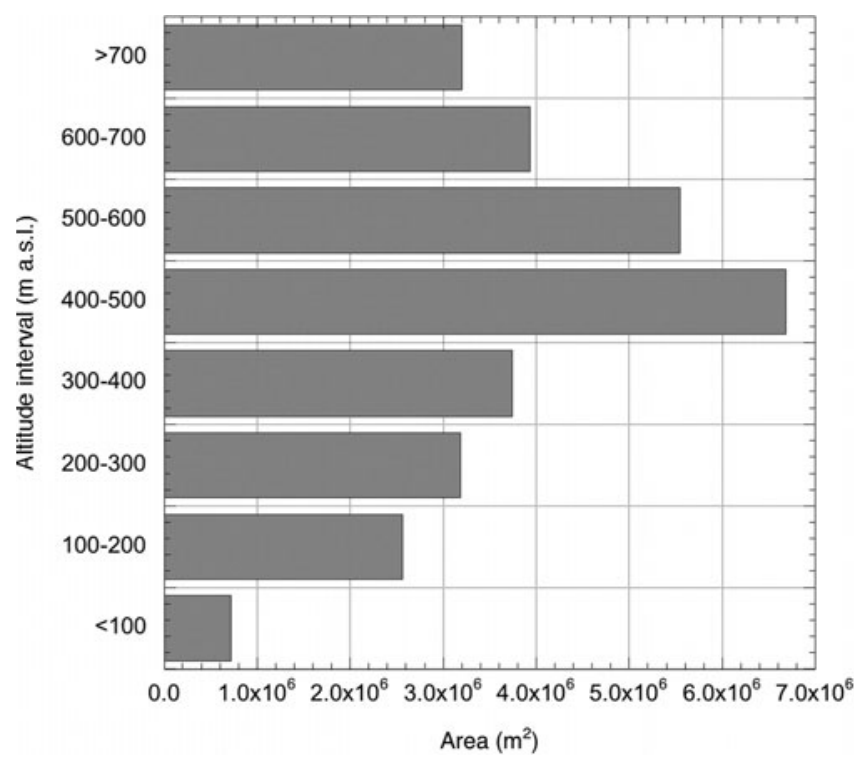

Fig. 2. Hypsometry of Finsterwalderbreen, based on 1990 surface topography. Sixty-five per cent of the glacier is above $400 \mathrm{~m}$ a.s.I. The GPS profile extends from 146(1990)/128(2003) ma.s.I. to $537(1990) / 556(2003) \mathrm{ma}$ a.s.l., and therefore samples the bulk of the glacier area.

rucksack while walking along. The resulting vertical accuracy of the survey is likely to be of the order of \pm 0.10 $0.15 \mathrm{~m}$. Note that the glacier already exhibits surface roughness of amplitude $\sim 0.50 \mathrm{~m}$, resulting from differential melting, supraglacial streams, structures such as primary stratification and foliation, and patchy snow at higher elevations. Hence the survey error is in effect smaller than error induced by the variable, irregular nature of the glacier surface itself. The impact of such errors is minimized by the long interval between surveys (13 years). The 2003 profile elevations were converted from vector to raster data with a $25 \mathrm{~m}$ gridcell size, to match the format of the 1990 DEM and ensure consistency by averaging out the small-scale surface roughness features discussed above.

\section{RESULTS}

The surface profiles from 1990 and 2003 are compared in Figure 3. It is immediately apparent that the difference between the two profiles is small: maximum elevation differences are -18 and $+19 \mathrm{~m}$, corresponding to changes of -1.25 and $+1.32 \mathrm{mw}$.e. $\mathrm{a}^{-1}$ (assuming ice density of $900 \mathrm{~kg} \mathrm{~m}^{-3}$ ), with a mean of $0.01 \mathrm{~m}$ over the length of the sampled profile. Although there is an overall increase in surface elevation change with altitude (Fig. 4), there is considerable spatial variation along the profile (Figs 3 and 4): up to about $2200 \mathrm{~m}$ distance, corresponding to altitudes up to about $230 \mathrm{~m}$, elevation change is negative, and strongly so at the lowermost elevations; from 2200 to $3400 \mathrm{~m}$ distance ( $\sim 230-300 \mathrm{~m}$ altitudes), elevation change is slightly positive; the zone from 3400 to $5800 \mathrm{~m}$ distance ( $300-410 \mathrm{~m}$ altitudes) is one of complex variation, though close to zero overall, and linear regression of altitude on elevation change puts the zero-change altitude in this zone at $\sim 330$ ma.s.l. (Fig. 4); beyond $5800 \mathrm{~m}$ on the profile, above $\sim 410 \mathrm{~m}$ altitude, elevation change is consistently positive, and strongly so at higher elevations (the maximum 


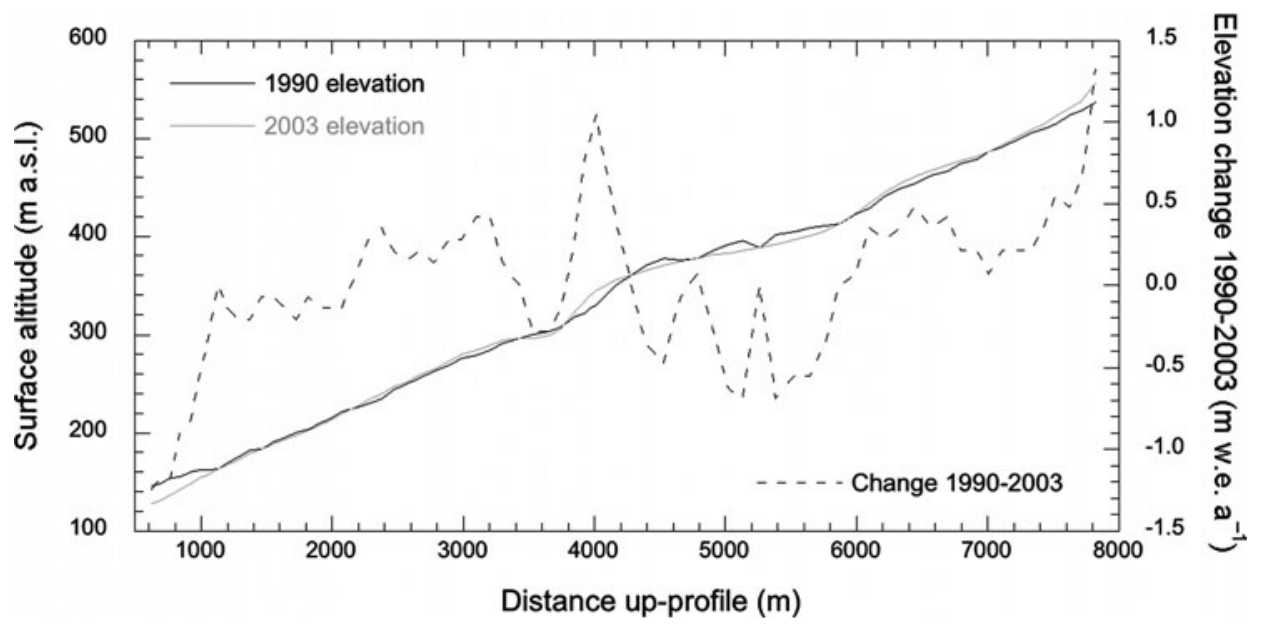

Fig. 3. 1990 and 2003 surface elevations, and elevation change with distance along the GPS profile. See text for further discussion.

altitude of the profile is $\sim 560 \mathrm{~m}$ ). Pinglot and others (1997) measured Finsterwalderbreen mass balance by detection of 1961-63 radioactive peaks, and noted that the net mass balance was essentially independent of altitude, which they attributed to the irregular topography of the glacier at high altitudes (cf. Fig. 4; Hodgkins and others, 2005).

The overall, area-weighted mean elevation change for the interval 1990-2003 depends to a small extent on extrapolation of changes to the zones below $100 \mathrm{~m}$ and above $600 \mathrm{~m}$ altitudes that are not sampled by the GPS profile. Using a logarithmic expression (elevation change $=$ $0.65 \ln$ (altitude) $-3.71, R^{2}=0.31$ ) to relate elevation change to altitude for these zones, which generates reasonable gradients in negative and positive changes at the extremes of the profiles, together with the means of the measured changes in the sampled zones, a value of $0.19 \mathrm{~m}$ w.e. $\mathrm{a}^{-1}$ is obtained. This value is therefore considered to be real, because the long interval between measurements (13 years) yields a large change signal (up to $19 \mathrm{~m}$ ), which mitigates noise such as interannual variability in snow extent and thickness. There are no other data (e.g. mass-balance measurements from stakes) covering this period; though this means there is no independent check on its accuracy, it underlines the utility of the GPS profiling approach.

\section{DISCUSSION}

Hagen and others (1999) used GPS profiling to measure mass-balance change on Kongsvegen, a $102 \mathrm{~km}^{2}$ glacier in northwest Spitsbergen, arguing that this was a valid approach since the annual flow rate on the glacier is very low $\left(2-3 \mathrm{~m} \mathrm{a}^{-1}\right)$ and the emergence velocity is almost negligible; furthermore, the mean annual altitude change from GPS was in good agreement with traditional stake measurements. Horizontal velocities at Finsterwalderbreen are higher than at Kongsvegen (up to $12-16 \mathrm{~m} \mathrm{a}^{-1}$ ) and the ice flux is a greater proportion of the balance velocity (up to $80 \%$ compared to $10 \%$ ), hence the surface-elevation change signal at Finsterwalderbreen is likely to be a more complex function of both cumulative surface mass-balance and ice dynamic response, though deconvoluting the two effects is an issue beyond the present scope of this paper.

The surge activity and quiescent-phase evolution of Finsterwalderbreen since 1898 have been described by
Liestøl (1969), Fox and Nuttall (1997), Nuttall and others (1997) and Nuttall and Hodgkins (2005). Whereas the lower glacier has thinned and retreated (by about $1.5 \mathrm{~km}$ ) since at least 1920, the central glacier ( $300-400 \mathrm{~m}$ altitude) has remained relatively constant, while above $400 \mathrm{~m}$ the glacier surface built up by about 5-15 m between 1970 and 1990 . These changes are consistent with the quiescent-phase evolution of the receiving area and reservoir area of a surge-type glacier. The topography of the upper accumulation area is complex, with several nunataks contributing to relatively irregular mass-balance and flow patterns (Fox and Nuttall, 1997; Hodgkins and others, 2005). Intermittent measurements of mass balance since 1950 (Liestøl, 1976; Hagen and Liestøl, 1990; Nuttall and others, 1997; Pinglot and others, 1997) have shown no significant trend, and

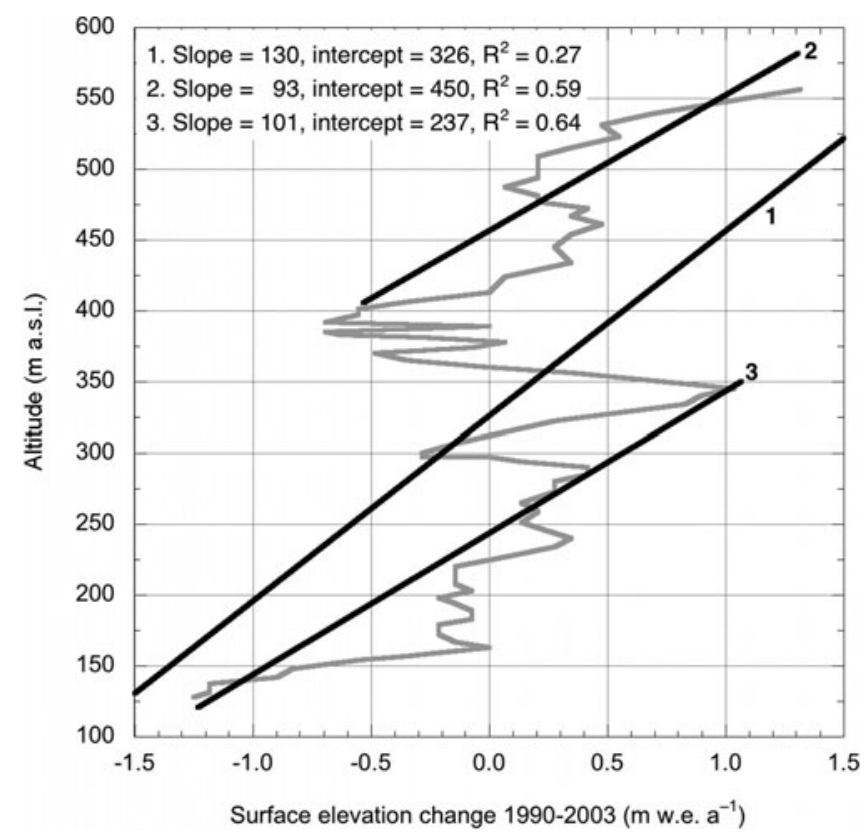

Fig. 4. Surface elevation with altitude. Linear regression 1 is significant with 95\% probability, though weak. Regressions 2 and 3 achieve much better fits with the same probability, by excluding the altitude interval 350-400 ma.s.l., the steepest part of the glacier with a locally negative elevation-change gradient (see Fig. 3). 
considerable interannual variability, with equilibrium-line altitudes (ELAs) varying between about 350 and $550 \mathrm{~m}$ a.s.l. The actual depth-averaged ice flux at $470 \mathrm{~m}$ altitude is 60 $80 \%$ of the balance flux (the variation resulting from interannual variability in ice velocity), based on measurements made over the period 1994-97 (Nuttall and others, 1997; Nuttall and Hodgkins, 2005). Assuming that the diverse measurements are all essentially accurate, there is a part of the glacier surface at about $300-400 \mathrm{~m}$ altitude which is reasonably stable and another at $400-500 \mathrm{~m}$ altitude which is thickening, despite zero or negative surface mass balance in these areas: this implies that the downglacier flux of ice is insufficient to compensate for the upglacier mass gain, which is consistent with balance velocity measurements and with the surge-type character of the glacier (Nuttall and others, 1997). This underlines the complexity of the relationship between surface massbalance and geometry change at a surge-type glacier where mass balance and ice flow are to some extent decoupled through low balance velocities.

Given the pattern of geometry change and the presence of a largely temperate bed (cf. Dowdeswell and others, 1995; Hodgkins and others, 1999), Nuttall and others (1997) conclude that Finsterwalderbeen is building up to a new surge, although the length of the quiescent phase may have been increased by the more adverse mass-balance conditions in Svalbard as a whole since about 1920, an assertion supported by analysis of looped medial moraines and the position of the terminus somewhat up-valley of the position immediately before the last surge (Nuttall and Hodgkins, 2005). Based on a lichenometric analysis of the terminal moraine complex, a further surge might, other factors being equal, be expected around 2025-30 (Hart and Watts, 1997).

The results presented here are very much consistent with the previous results described above. Over 1990-2003, the lowermost part of the glacier has continued to thin and retreat (see also Nuttall and Hodgkins, 2005, fig. 2), with a minimum surface elevation change of -1.25 mw.e. $\mathrm{a}^{-1}$ recorded here, though greater thinning is likely at lower elevations not sampled by the GPS profile. Between 300 and $400 \mathrm{~m}$ altitude, Finsterwalderbreen has been essentially stable over the same period, with surface elevation change varying spatially between -0.69 and 1.04 m w.e. $\mathrm{a}^{-1}$ (mean of $0.02 \mathrm{~m}$ w.e. $\mathrm{a}^{-1}$ ). Above $400 \mathrm{~m}$ altitude, the glacier surface has continued to build up at rates similar to those recorded from previous decades: build-up rates over 1970-90 were 0.23-0.68 mw.e. $\mathrm{a}^{-1}$ (Nuttall and others, 1997), whereas over 1990-2003 they were 0.05-0.60 mw.e. $\mathrm{a}^{-1}$ (although elevations above $600 \mathrm{~m}$ were not sampled by the GPS profile and higher values might have been recorded if that had been the case, given the trends displayed in Figure 4).

The results presented here can also be assessed to some extent in the light of climate variation. The North Atlantic Oscillation (NAO) index was generally more positive over the interval 1990-2003 than it was over 1970-90, a pattern associated with increased ocean temperatures and increased meridional moisture flux in the Atlantic Arctic sector as a whole. At Svalbard airport, there was no strong airtemperature trend over 1970-90, but there was a strong trend in winter temperatures from 1990 onwards (Førland and Hanssen-Bauer, 2003). Precipitation totals at Svalbard airport were largely steady from 1970 to 1990, and declining slightly from 1990 onwards (suggesting only a weak association between the NAO and Svalbard precipitation). These patterns suggest that more positive NAO conditions in Svalbard may be associated with a more negative massbalance situation, with the dominant influences of warmer winter temperatures being a decrease in the proportion of solid precipitation (Førland and Hanssen-Bauer, 2003) and a shorter accumulation season. End-of-winter accumulation was measured at Finsterwalderbreen for 6 out of 7 years from 1994 to 2000, with no trend; for the whole glacier the mean annual accumulation was $0.53 \pm 0.15$ mw.e., or $0.62 \pm 0.12 \mathrm{~m}$ w.e. for the part of the glacier experiencing zero or positive elevation change over 1990-2003.

\section{CONCLUSIONS}

GPS profiling offers a useful way to collect elevation-change data, and therefore to determine glacier geometry change, with a greater spatial coverage than traditional stake networks, because systems operating in rover (kinematic differential) mode can sample at $\mathrm{Hz}$ frequencies from moving vehicles or even, as in this case, by operators on foot. The level of accuracy achieved is acceptable, particularly when measuring intervals are several years or more and elevation changes are likely to be several metres or more. Furthermore, it is a flexible approach that offers the potential to increase the range of glacier types and sizes that can be monitored in a given time, and can therefore contribute to the reduction of uncertainty in cryospheric trend synthesis and modelling. Disadvantages of the technique include the fact that the measured elevation change is a function of both surface mass-balance change and ice flow, and without supporting data it is not possible to separate the relative influence of each. Nevertheless, the combination of GPS profiling with pre-existing, photogrammetrically derived DEM data has here allowed an assessment of the continued geometric evolution of Finsterwalderbreen, a glacier which has been observed and measured episodically since 1898 . Despite indications from Svalbard weather-station data that accumulation conditions have probably become somewhat more adverse since 1990, the change in surface elevation between then and 2003 has been consistent with that noted between 1970 and 1990, and reflects the anticipated evolution of a surge-type glacier, with down-glacier/ receiving area wasting of up to $-1.25 \mathrm{mw}$.e. $\mathrm{a}^{-1}$, and upglacier/reservoir area build-up of up to $0.60 \mathrm{~m}$ w.e. $\mathrm{a}^{-1}$. The boundary between elevation loss and elevation gain is complex and does not necessarily correspond with the surface-measured ELA (though that displays large interannual variability). It therefore appears that Finsterwalderbreen continues to build towards a new surge event.

\section{ACKNOWLEDGEMENTS}

Funding was provided by Royal Holloway, University of London, and Liverpool John Moores University and by the British Antarctic Survey.

\section{REFERENCES}

Dowdeswell, J.A., R. Hodgkins, A.-M. Nuttall, J.O. Hagen and G.S. Hamilton. 1995. Mass balance change as a control on the frequency and occurrence of glacier surges in Svalbard, Norwegian High Arctic. Geophys. Res. Lett., 22(21), 2909-2912. 
Dyurgerov, M.B., V.B. Aizin and A.B. Buynitskiy. 1985. Nakopleniye massy $v$ oblasti pitaniya lednika Medvezh'yego za periody mezhdu yego podvizhkami [Mass accumulation in the accumulation area of Medvezhiy Glacier during its quiesence [sic] periods]. Mater. Glyatsiol. Issled./Data Glaciol. Stud. 54, 131-135.

Eisen, O., W.D. Harrison and C.F. Raymond. 2001. The surges of Variegated Glacier, Alaska, U.S.A., and their connection to climate and mass balance. J. Glaciol., 47(158), 351-358.

Førland, E.J. and I. Hanssen-Bauer. 2003. Past and future climate variations in the Norweigan Arctic: overview and novel analysis. Polar Res., 22(2), 113-124.

Fox, A.J. and A.-M. Nuttall. 1997. Photogrammetry as a research tool for glaciology. Photogramm. Rec., 15(89), 725-737.

Hagen, J.O. and O. Liestøl. 1990. Long-term glacier mass-balance investigations in Svalbard, 1950-88. Ann. Glaciol., 14, 102-106.

Hagen, J.O., K. Melvold, T. Eiken, E. Isaksson and B. Lefauconnier. 1999. Mass balance methods on Kongsvegen, Svalbard. Geogr. Ann., 81A(4), 593-601.

Hagen, J.O., B. Etzelmüller and A.-M. Nuttall. 2000. Runoff and drainage pattern derived from digital elevation models, Finsterwalderbreen, Svalbard. Ann. Glaciol., 31, 147-152.

Hagen, J.O., J. Kohler, K. Melvold and J.-G. Winther. 2003. Glaciers in Svalbard: mass balance, runoff and freshwater flux. Polar Res. 22(2), 145-159.

Hamilton, G.S. and J.A. Dowdeswell. 1996. Controls on glacier surging in Svalbard. J. Glaciol., 42(140), 157-168.

Hart, J.K. and R. Watts. 1997. A comparison of the styles of deformation associated with two recent push moraines, south Van Keulenfjorden, Svalbard. Earth Surf. Process. Landf., 22(12), 1089-1107.

Hodgkins, R., J.O. Hagen and S.E. Hamran. 1999. 20th-century mass balance and thermal regime change at Scott Turnerbreen, Svalbard. Ann. Glaciol., 28, 216-220.

Hodgkins, R., R. Cooper, J. Wadham and M. Tranter. 2003. Suspended sediment fluxes in a high-Arctic glacierised catchment: implications for fluvial sediment storage. Sediment. Geol., 162(1-2), 105-117.
Hodgkins, R., R. Cooper, J. Wadham and M. Tranter. 2005. Interannual variability in the spatial distribution of winter accumulation at a high-Arctic glacier (Finsterwalderbreen, Svalbard), and its relationship with topography. Ann. Glaciol., 42, 243-254.

Jiskoot, H., P. Boyle and T. Murray. 1998. The incidence of glacier surging in Svalbard: evidence from multivariate statistics. Comput. Geosci., 24(4), 387-399.

Lefauconnier, B. and J.O. Hagen. 1990. Glaciers and climate in Svalbard: statistical analysis and reconstruction of the Brøggerbreen mass balance for the last 77 years. Ann. Glaciol., 14, 148-152.

Lefauconnier, B. and J.O. Hagen. 1991. Surging and calving glaciers in eastern Svalbard. Nor. Polarinst. Medd. 116

Liestøl, O. 1969. Glacier surges in West Spitsbergen. Can. J. Earth Sci., 6(4), 895-897.

Liestøl, O. 1976. Glaciological work in 1974. Nor. Polarinst. Årb. 1974, 183-194.

Nuttall, A.M. and R. Hodgkins. 2005. Temporal variations in flow velocity at Finsterwalderbreen, a Svalbard surge-type glacier. Ann. Glaciol., 42, 71-76.

Nuttall, A.-M., J.O. Hagen and J. Dowdeswell. 1997. Quiescentphase changes in velocity and geometry of Finsterwalderbreen, a surge-type glacier in Svalbard. Ann. Glaciol., 24, 249-254.

Ødegård, R.S., J.O. Hagen and S.E. Hamran. 1997. Comparison of radio-echo sounding $(30-1000 \mathrm{MHz})$ and high-resolution borehole-temperature measurements at Finsterwalderbreen, southern Spitsbergen, Svalbard. Ann. Glaciol., 24, 262-267.

Pinglot, J.F., M. Pourchet, B. Lefauconnier and M. Creseveur. 1997. Equilibrium line and mean annual mass balance of Finsterwalderbreen, Spitsbergen, determined by in situ and laboratory gamma-ray measurements of nuclear test deposits. Ann. Glaciol., 24, 54-59.

Wadham, J.L., R. Hodgkins, R.J. Cooper and M. Tranter. 2001. Evidence for seasonal subglacial outburst events at a polythermal glacier, Finsterwalderbreen, Svalbard. Hydrol. Process., 15(12), 2259-2280. 